FE641

\title{
A Survey of Educational Program Needs for the Florida Association of Counties County Commissioner Training Program, 2002-2004
}

\author{
Rodney L. Clouser
}

\section{INTRODUCTION}

Florida Cooperative Extension has partnered with the Florida Association of Counties (FAC) and the Florida Counties Foundation (FCF) since 1998 in surveying Florida County Commissioners and County Administrators approximately every two years. The survey collects information regarding attendance at FAC-FCF sponsored events, willingness to pay for educational programs, worth of events and programs attended by commissioners and administrators, desired locations for educational activities and, most importantly, the type and amount of training needed by commissioners on various topics that would assist them as an elected policy maker.

The results of the 2002-04 survey are presented as an executive summary that follows. In addition, the survey questionnaire and PowerPoint presentation of results are being made available via a link for those who would like to view or print the entire document.

\footnotetext{
The Institute of Food and Agricultural Sciences (IFAS) is an Equal Opportunity Institution authorized to provide research, educational information, and other services only to individuals and institutions that function with non-discrimination with respect to race, creed, color, religion, age, disability, sex, sexual orientation, marital status, national origin, political opinions, or affiliations. U.S. Department of Agriculture, Cooperative Extension Service, University of Florida, IFAS, Florida A\&M University Cooperative Extension Program, and Boards of County Commissioners. Larry Arrington, Dean.
}

This is EDIS document FE641, a publication of the Food and Resource Economics Department, Florida Cooperative Extension Service, Institute of Food and Agricultural Sciences, University of Florida, Gainesville, FL. Published June 2006. Please visit the EDIS website at http://edis.ifas.ufl.edu. 


\title{
A Survey of Educational Program Needs for the Florida Association of Counties County Commissioner Training Program, 2002-2004
}

\author{
Rodney L. Clouser ${ }^{1}$
}

\section{EXECUTIVE SUMMARY}

\section{2-2004 County Commissioner and County Administrator Educational Survey}

A survey of educational program needs for Florida County Commissioners and County Administrators was conducted by the Florida Counties Foundation (FCF) and Florida Cooperative Extension Service (FCES), Institute of Food and Agricultural Sciences (IFAS), University of Florida during the spring of 2002. The intent of the survey was to solicit educational training needs to assist FCF in developing educational programs for 2002-2004. A total of 373 County Commissioners and 65 County Administrators were surveyed.

Response rates set a new record. By June 7, 2002, a total of 219 questionnaires were returned and included in this analysis. An additional 10 questionnaires have been received but were not included in the analysis. The number of responses received by June 7, 2002, represents a return rate of 50 percent. This is return rate represents an increase of over 50 percent more responses returned than in any previous survey. The response rate is approximately four-fold larger than the first survey conducted by FCF. A summary of the survey results follows:

1. Over four in ten commissioners and administrators attend the Florida Association of Counties (FAC) annual conference on a regular basis, and over seven in ten attend the conference regularly or periodically. Regular attendance at the annual conference is slightly higher from commissioners and administrators representing rural counties.

2. The number of officials who attend the annual legislative conference is similar to the number who attends the annual conference. However, regular attendance at the annual legislative conference is about 15 percent higher from commissioners and administrators in rural counties than from urban counties.

3. Over 67 percent of all respondents have attended an FCF educational program at some point in time. A significantly larger number of officials in rural counties (82 percent) compared to urban counties (55 percent) attended educational programs.

4. Not only are rural officials more regular attendees at educational programs, but 50 percent attended two or more educational programs, compared to 40 percent of urban commissioners and administrators.

\footnotetext{
1 Professor and Extension Public Policy Specialist, Food and Resource Economics Department, University of Florida, Gainesville, FL.
} 
5. Over 50 percent of county officials found FCF educational programs at least sometimes beneficial while less than five percent found them never to be beneficial.

6. Overall, Friday was the most preferred day for training, followed closely by Tuesday. While preferences by urban officials were identical to the overall preference, rural commissioners' and administrators' top choices for training were Tuesday and Wednesday.

7. Seven out of ten commissioners and administrators preferred programs lasting at least a half-day but no longer than a whole day. Slightly more officials preferred whole day programs.

8. Tallahassee was the preferred choice for educational program location for rural counties and Orlando was the preferred choice for urban counties. Overall, Orlando was the top choice, followed by Tallahassee. If trainings were held in Orlando, Tallahassee, and in the Gainesville to Jacksonville corridor, they would cover the preferred location for over 75 percent of all county officials.

9. Over 55 percent of commissioners and administrators preferred workshops that covered multiple education topics rather than single topics.

10. Slightly over 60 percent of county officials would pay up to $\$ 125$ to attend educational programs.

11. The most important factor in determining attendance at workshops was the topic being covered, followed by program location and program date/time. Receiving certification credit was a more important determinant for rural officials than for urban officials regarding attendance but still ranked behind the three previously identified determinants.

12. Over 70 percent of those responding agreed or strongly agreed that the voluntary County Commissioner Certification program should be continued.

13. The top five training programs weighted by total points received were growth management, economic development, land use planning and zoning, grants, and environment/land/water issues. The only difference between rural and urban counties was that rural counties ranked grant training programs in the top five and urban counties ranked E-government topics as a top five training need. The lowest ranked training programs were sexual harassment, time/tress management, government in the sunshine, and county government form and function (in that order). All other training programs received a total vote within 20 percent of the top five training programs previously identified, except for charter government and home rule, which was approximately 30 percent lower than the highest rated topic.

14. In terms of total votes received as a topic that was a "most important training” need, the overall rankings identified growth management, economic development, and budgeting as the top needs. The most important issues in rural counties were budgeting, economic development, grants, and alternative revenues. In urban counties, the top training needs were growth management, economic development, and budgeting. 
15. About 28 percent of survey respondents indicated they were CCC graduates.

16. Of the CCC graduates, about 70 percent would attend an alumni event if organized.

17. Of the CCC graduates, over 77 percent indicated they would participate in an advanced curriculum program.

18. Over 70 percent of county officials responding to the survey had served eight years or less in their positions. One in four county officials has held his/her current position two years or less.

\section{Summary}

Participation and returns of surveys by county commissioners and county administrators are at high levels. Prior to the University of Florida Cooperative Extension becoming involved with the survey in 1998, the typical response rate was about 15 percent. The survey response rate increased to 32 percent in 1998, and increased to over 50 percent in 2002.

From an educational standpoint, the most important education needs of those serving as county commissioners or administrators are:

- The top five training programs weighted by total points were growth management, economic development, land use planning and zoning, grants, and environment/land/water issues.

- The only difference between rural and urban counties was that rural counties ranked grant training programs in the top five and urban counties ranked E-government topics as a top five training need. 


\section{FLORIDA COUNTIES FOUNDATION}

County Commissioners Voluntary Certification Program Survey

1. How often do you attend the Florida Association of Counties (FAC) Annual Conference?
Always
Sometimes
Rarely Never

2. How often do you attend the FAC Legislative Conference and/or Legislative Day?

_ Always __ Sometimes__ Rarely _ _ Never

3. Have you attended Florida Counties Foundation (FCF) educational programs in the past?

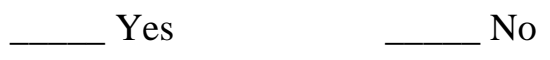

4. What was the total number of FCF educational/County Commissioner Certification (CCC) programs that you attended in the last year?

$\begin{array}{cc}\text { None } & \text { If None, go to Question } 6 . \\ \text { One } & \text { Two or three } \quad \text { T More than three }\end{array}$

5. How beneficial were the FCF/CCC educational programs that you attended?

Always beneficial

Sometimes beneficial

Never beneficial `

No opinion

6. What day(s) do you prefer for attending workshops? (mark only one)

_ Weekend Workshops Friday/Saturday Workshops

Weekday Workshops (please indicate your preferred day

7. What length and time of day do you prefer for workshops? (mark only one)

Half Day (3 hours) _ $\quad$ Whole Day (7 hours) _ _ Multiple Days (14 hours)
Evenings

8. Of the following locations (city/county), which would you prefer most (mark only one)

Orlando/Orange County

Tallahassee/Leon County

Gainesville/Alachua County
Tampa/Hillsborough County Jacksonville/Duval County West Palm Beach/Palm Beach County 
9. Do you prefer single subject or multiple subject workshops?

Single subjects (example: budgeting)

Multiple subjects (example: budgeting, ethics, conflict resolution)

10. The registration fee for the Foundation's certification (CCC) program is $\$ 98$ and it barely covers program costs. To enhance the program and expand course offerings, what is the most that you would pay for the registration fee?
No increase
Up to $\$ 125$
$\$ 150$ to $\$ 175$
More than $\$ 175$

11. How important are the following factors in deciding to attend workshops? (please rate each item with 1 being low importance and 5 being high importance)

\begin{tabular}{lcccccc} 
& $\begin{array}{c}\text { Low } \\
\text { Importance }\end{array}$ & & & High & No \\
Importance & Opinion \\
\hline Topic & 1 & 2 & 3 & 4 & 5 & 6 \\
Fee & 1 & 2 & 3 & 4 & 5 & 6 \\
Date/Time & 1 & 2 & 3 & 4 & 5 & 6 \\
Location & 1 & 2 & 3 & 4 & 5 & 6 \\
Length (12/, full day, etc.) & 1 & 2 & 3 & 4 & 5 & 6 \\
Certification Credit & 1 & 2 & 3 & 4 & 5 & 6
\end{tabular}

12. Do you agree or disagree with the statement, "The County Commissioners Voluntary Certification Program should be continued.”

Strongly Agree
Agree
N_ Neither Agree Nor Disagree
Disagree
Strongly Disagree
No Opinion


13. What amount of training do you need on the following topics to do your job better? (circle one number for the amount of training needed for each topic)

Amount of Training Needed

\begin{tabular}{|c|c|c|c|c|c|c|}
\hline & & None & A Little & Some & A Lot & $\begin{array}{l}\text { Not } \\
\text { Sure }\end{array}$ \\
\hline a. & Alternative revenues (ie., MSTUs and Special Assessments & 1 & 2 & 3 & 4 & 5 \\
\hline b. & Bonding issues & 1 & 2 & 3 & 4 & 5 \\
\hline c. & Budgeting and financial management & 1 & 2 & 3 & 4 & 5 \\
\hline d. & Charter government and home rule & 1 & 2 & 3 & 4 & 5 \\
\hline e. & Conflict resolution & 1 & 2 & 3 & 4 & 5 \\
\hline f. & Constituent relations/Customer service & 1 & 2 & 3 & 4 & 5 \\
\hline g. & County government form \& function & 1 & 2 & 3 & 4 & 5 \\
\hline h. & County government roles \& responsibilities & 1 & 2 & 3 & 4 & 5 \\
\hline i. & E-government & 1 & 2 & 3 & 4 & 5 \\
\hline j. & Economic development & 1 & 2 & 3 & 4 & 5 \\
\hline k. & Effective communications & 1 & 2 & 3 & 4 & 5 \\
\hline 1. & Environment/water/land use & 1 & 2 & 3 & 4 & 5 \\
\hline $\mathrm{m}$. & Ethics & 1 & 2 & 3 & 4 & 5 \\
\hline n. & Government in the sunshine/Sunshine law & 1 & 2 & 3 & 4 & 5 \\
\hline 0. & Grants & 1 & 2 & 3 & 4 & 5 \\
\hline p. & Growth management & 1 & 2 & 3 & 4 & 5 \\
\hline q. & Health \& human services & 1 & 2 & 3 & 4 & 5 \\
\hline r. & Land use, planning, and zoning & 1 & 2 & 3 & 4 & 5 \\
\hline s. & Leadership training & 1 & 2 & 3 & 4 & 5 \\
\hline t. & Legislative process & 1 & 2 & 3 & 4 & 5 \\
\hline u. & Media/Presentation skills & 1 & 2 & 3 & 4 & 5 \\
\hline $\mathrm{v}$. & Negotiating skills & 1 & 2 & 3 & 4 & 5 \\
\hline w. & Personnel policies/Labor law/Employee relations & 1 & 2 & 3 & 4 & 5 \\
\hline $\mathrm{x}$. & Public safety (including, but not limited to terrorist threats) & 1 & 2 & 3 & 4 & 5 \\
\hline $\mathrm{y}$. & Sexual harassment & 1 & 2 & 3 & 4 & 5 \\
\hline $\mathrm{z}$. & Time/Stress management & 1 & 2 & 3 & 4 & 5 \\
\hline aa. & Other: & 1 & 2 & 3 & 4 & 5 \\
\hline
\end{tabular}

14. Of the topics listed in Question 13, which are the most important to helping you do a better job? (please identify by alphabetical character the top 3 training needs) 
15. Are you a CCC graduate?
Yes
No
If No, go to Question 18

16. If organized, would you attend an alumni event for CCC graduates only?

Yes $\quad$ No

17. If organized, would you participate in an advanced curriculum program for CCC graduates only?

Y Yes $\quad$ No

18. How many years have you held your current position?

Less than 2 years

2-8 years

9-12 years

More than 12 years

Optional: Name

County:

Return in enclosed SASE to:

Dr. Rodney L. Clouser or

Fax to: (352) 392-5259

\section{Please return within 5 days of receipt}

Thanks for your assistance 


\section{2-04 County Commissioner Educational Survey}

Rodney L. Clouser 


\section{Attendance At FAC Annual Conference}

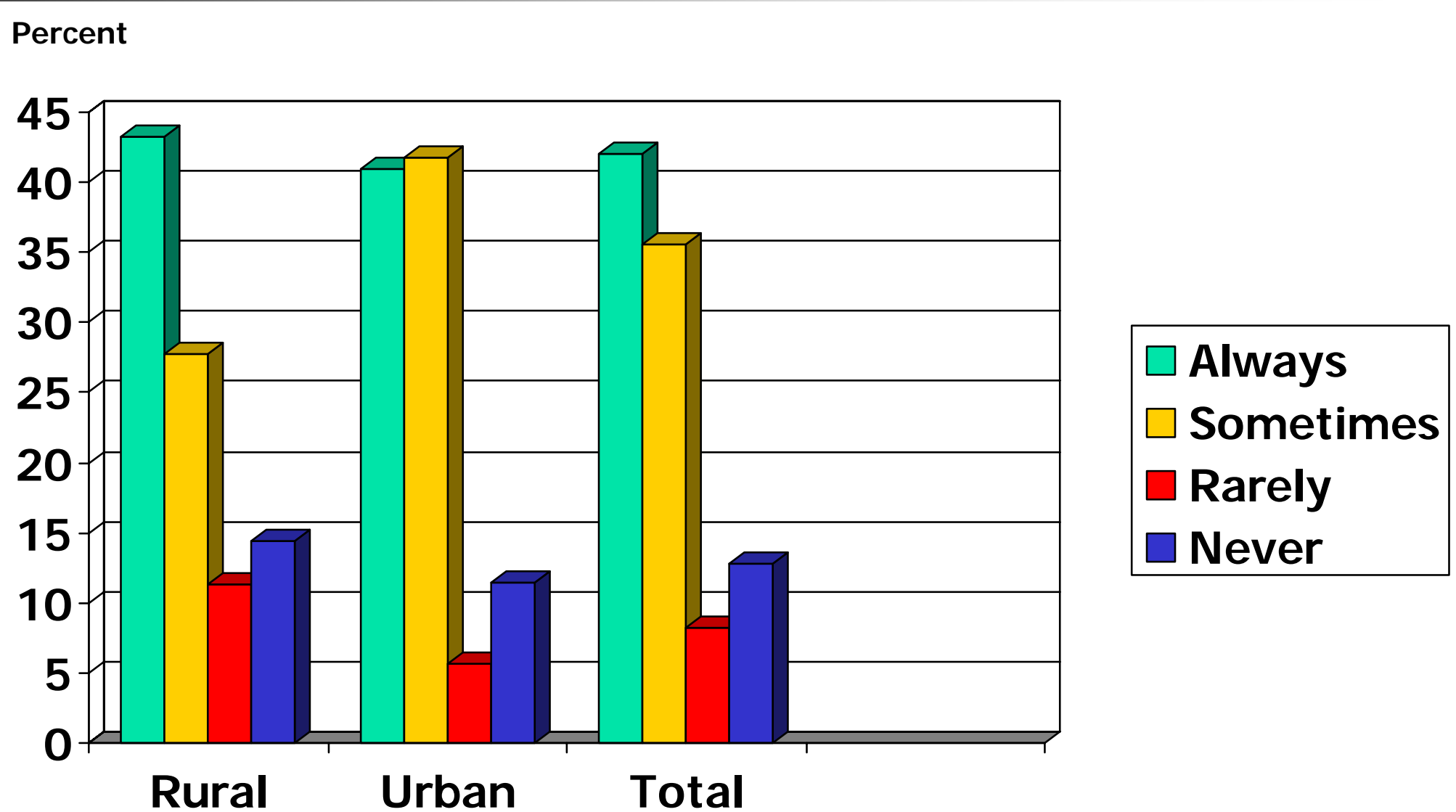




\section{Attendance At FAC Legislative Conference and/ or Legislative Day}

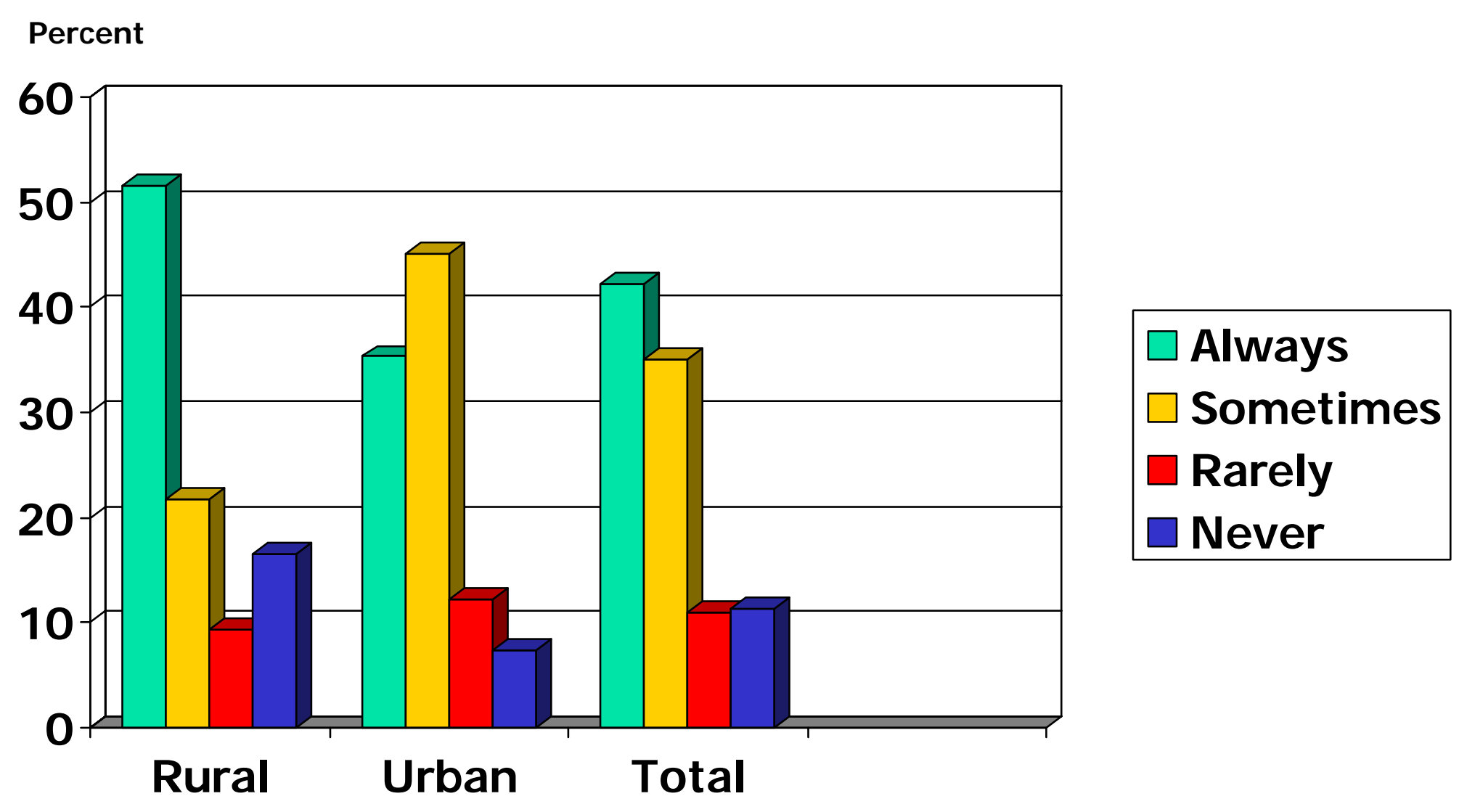




\section{Have You Attended FCF Educational Programs In The Past}

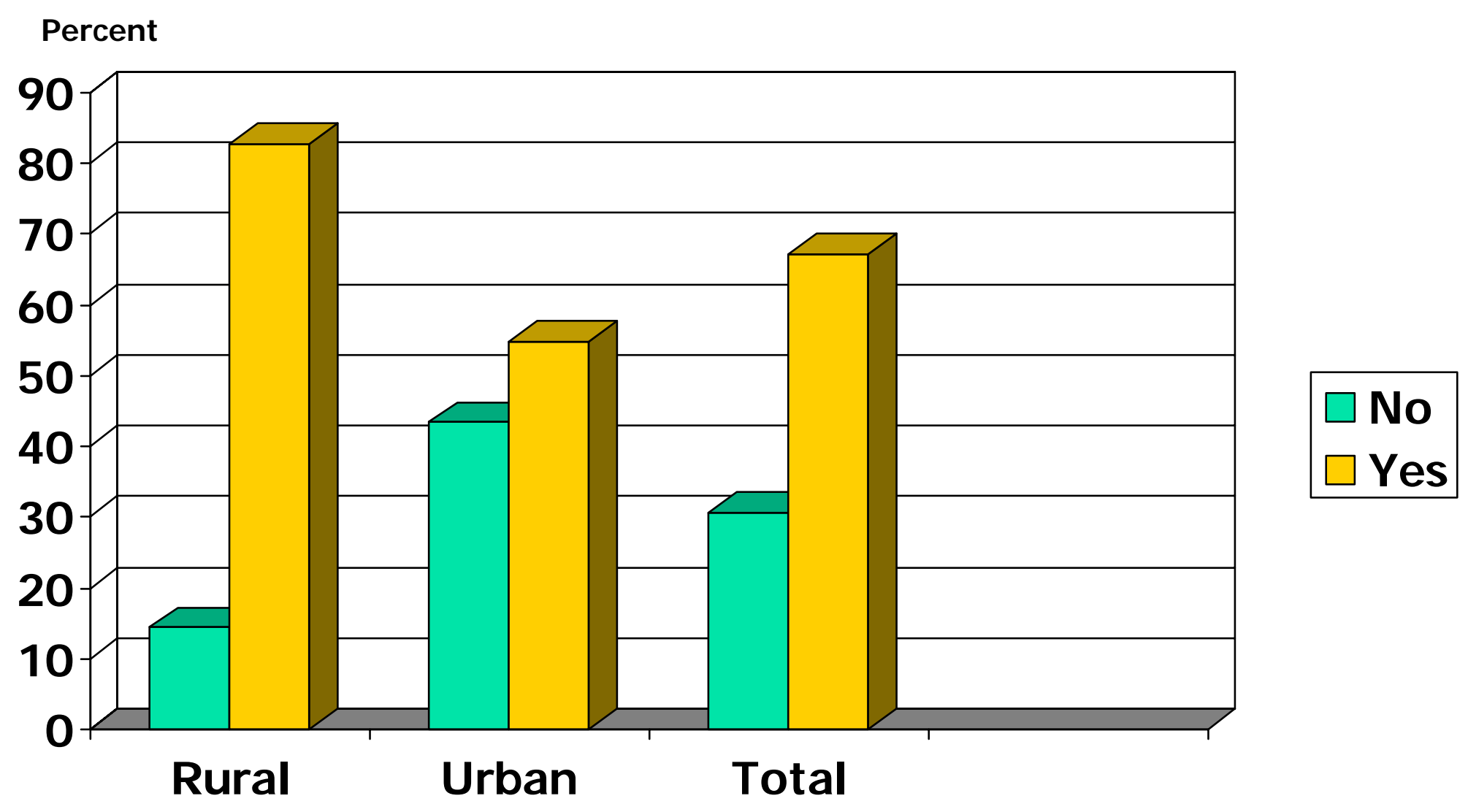




\section{How Many FCF Certification Programs Have You Attended I n Last Year}

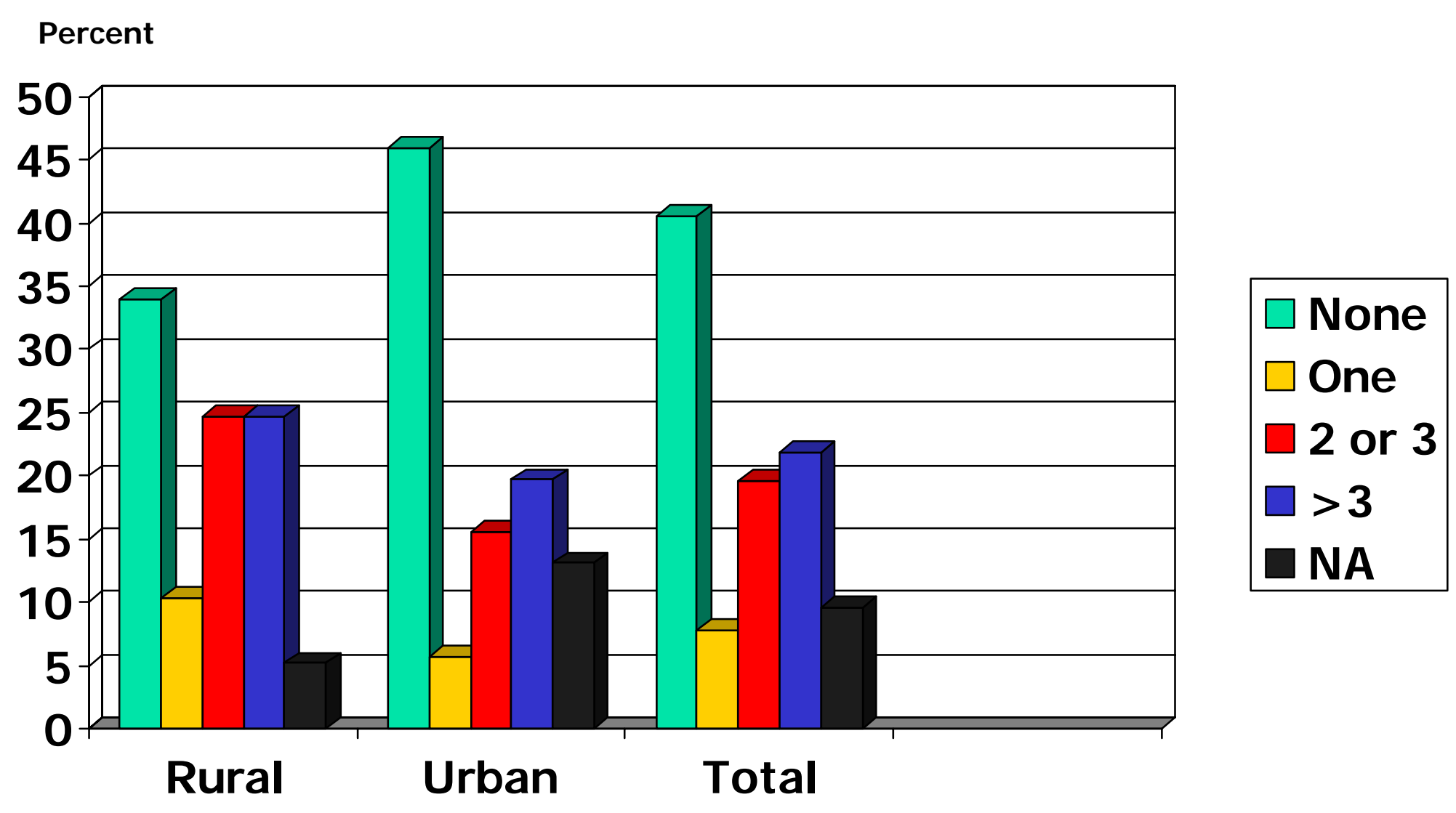




\section{How Beneficial Were the FCF Programs That You Attended}

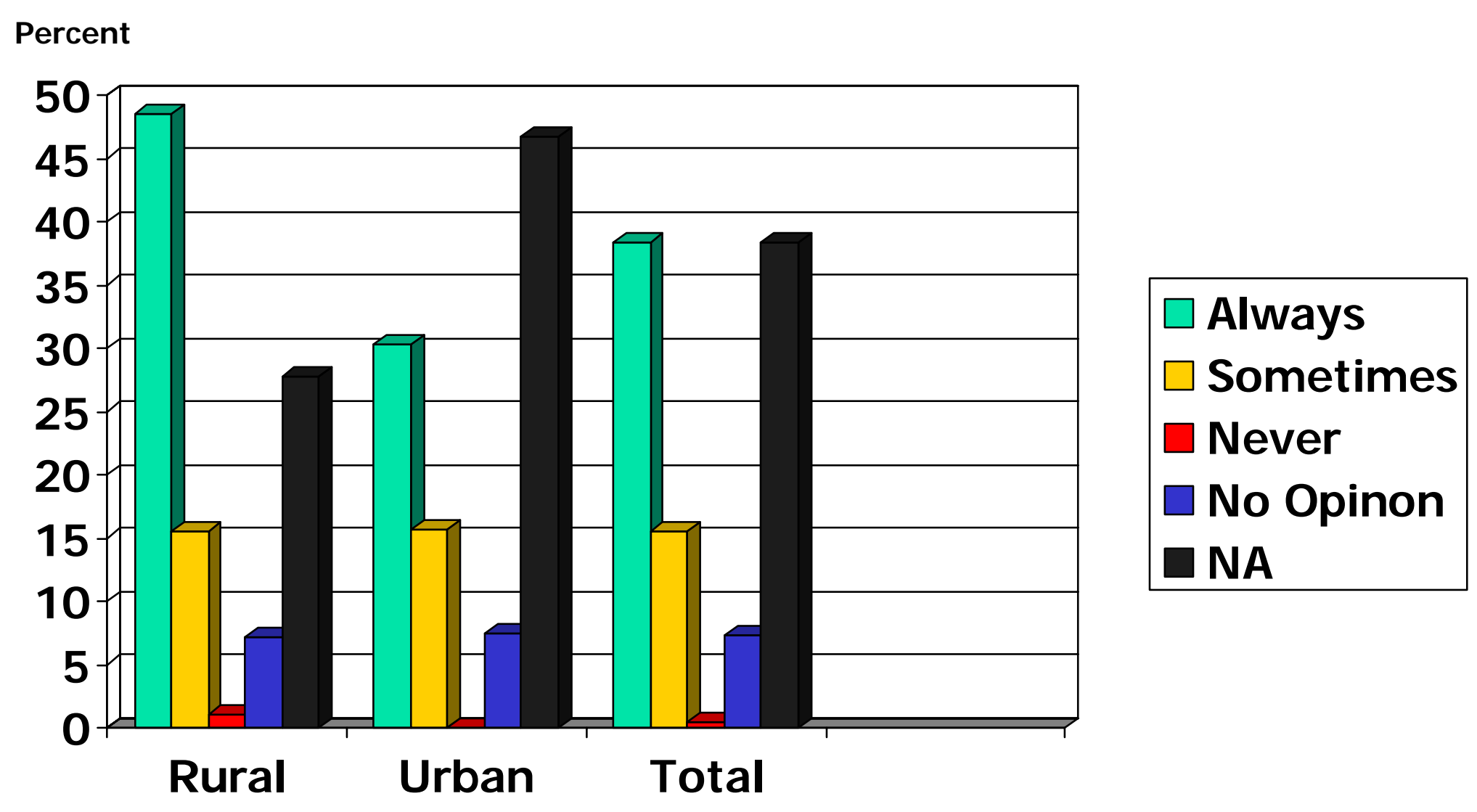




\section{What Days Do You Prefer To Attend Workshops}

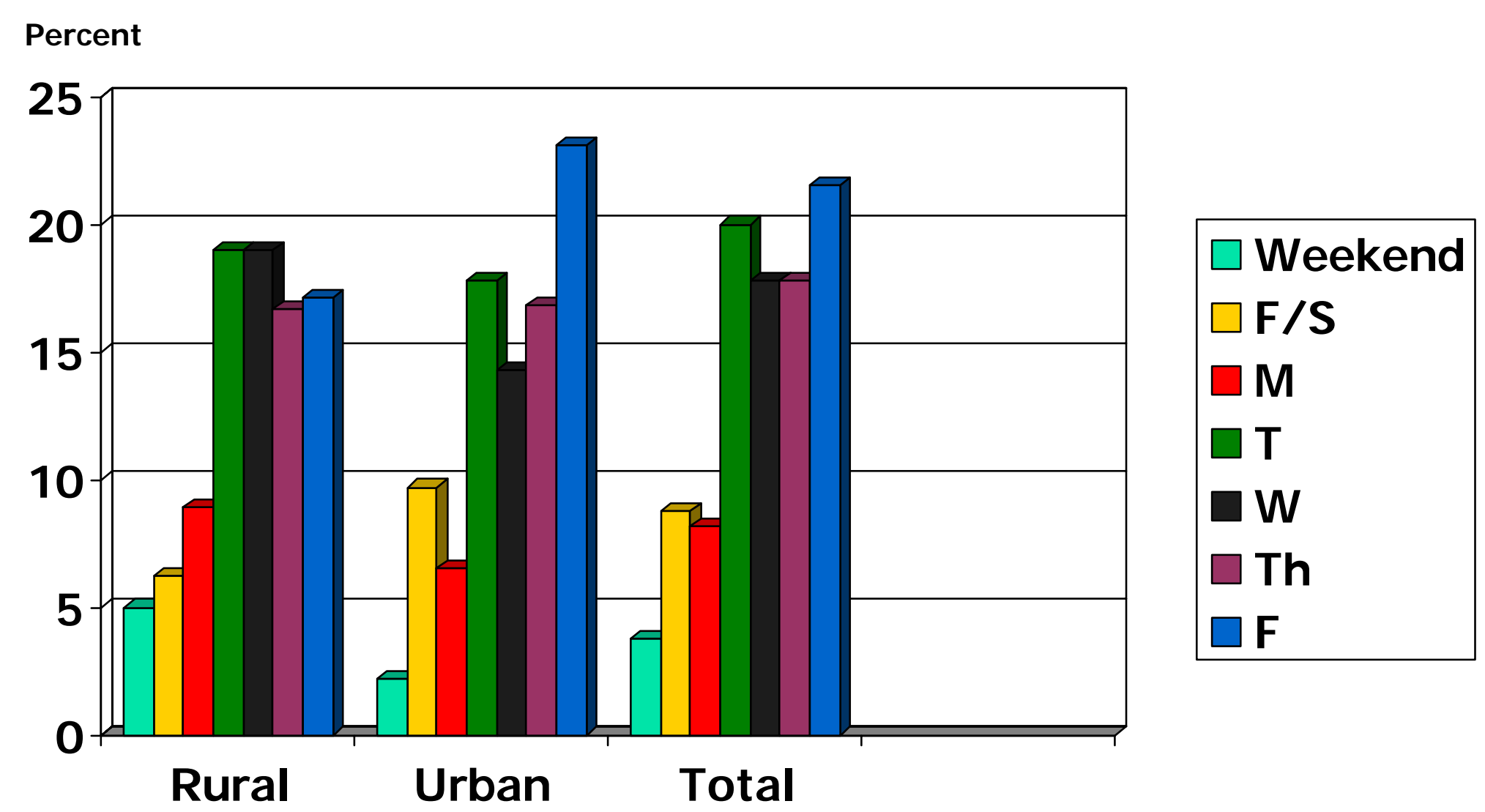




\section{What Length and Time Do You Prefer For Workshops}

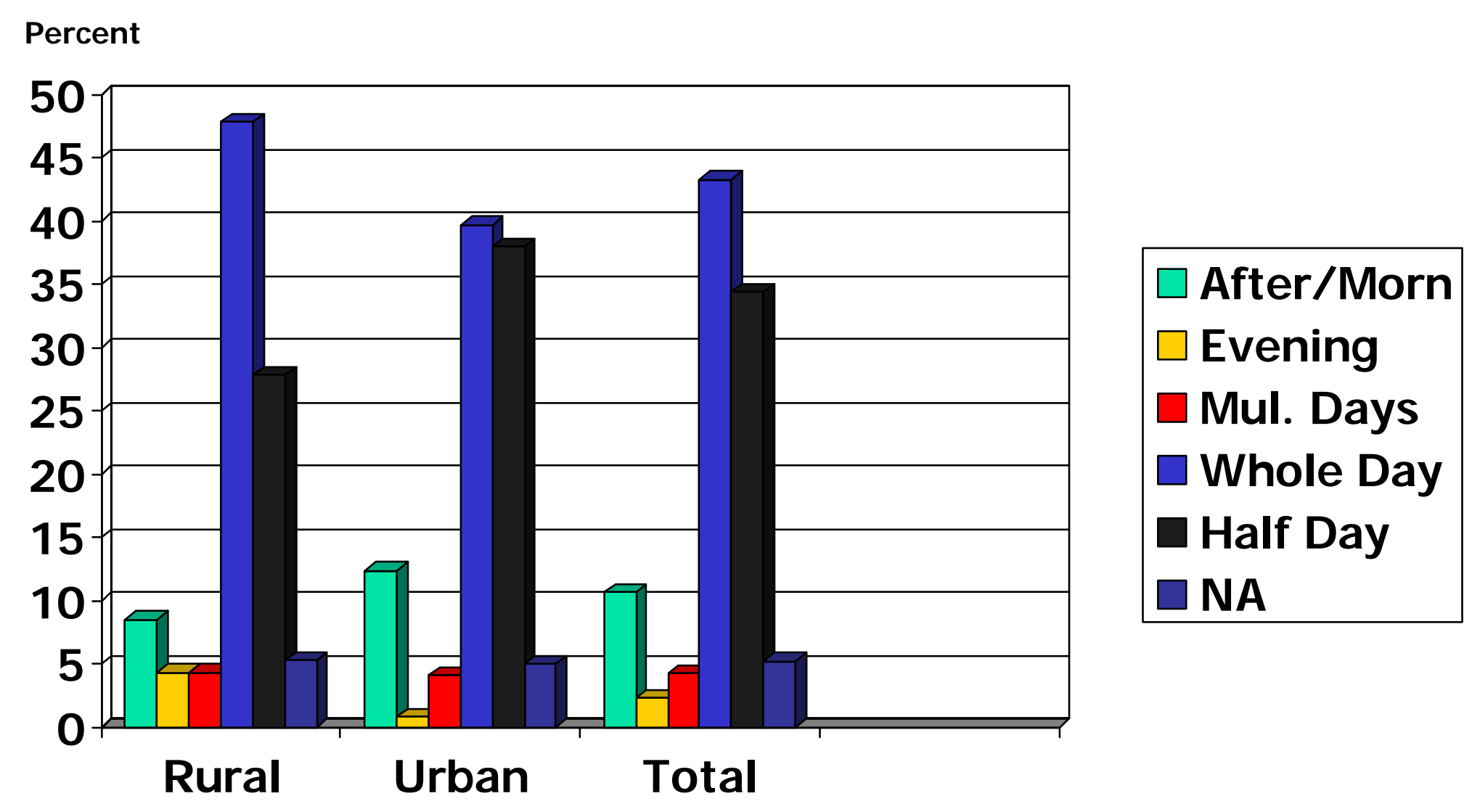




\section{What Location Would You Prefer Most}

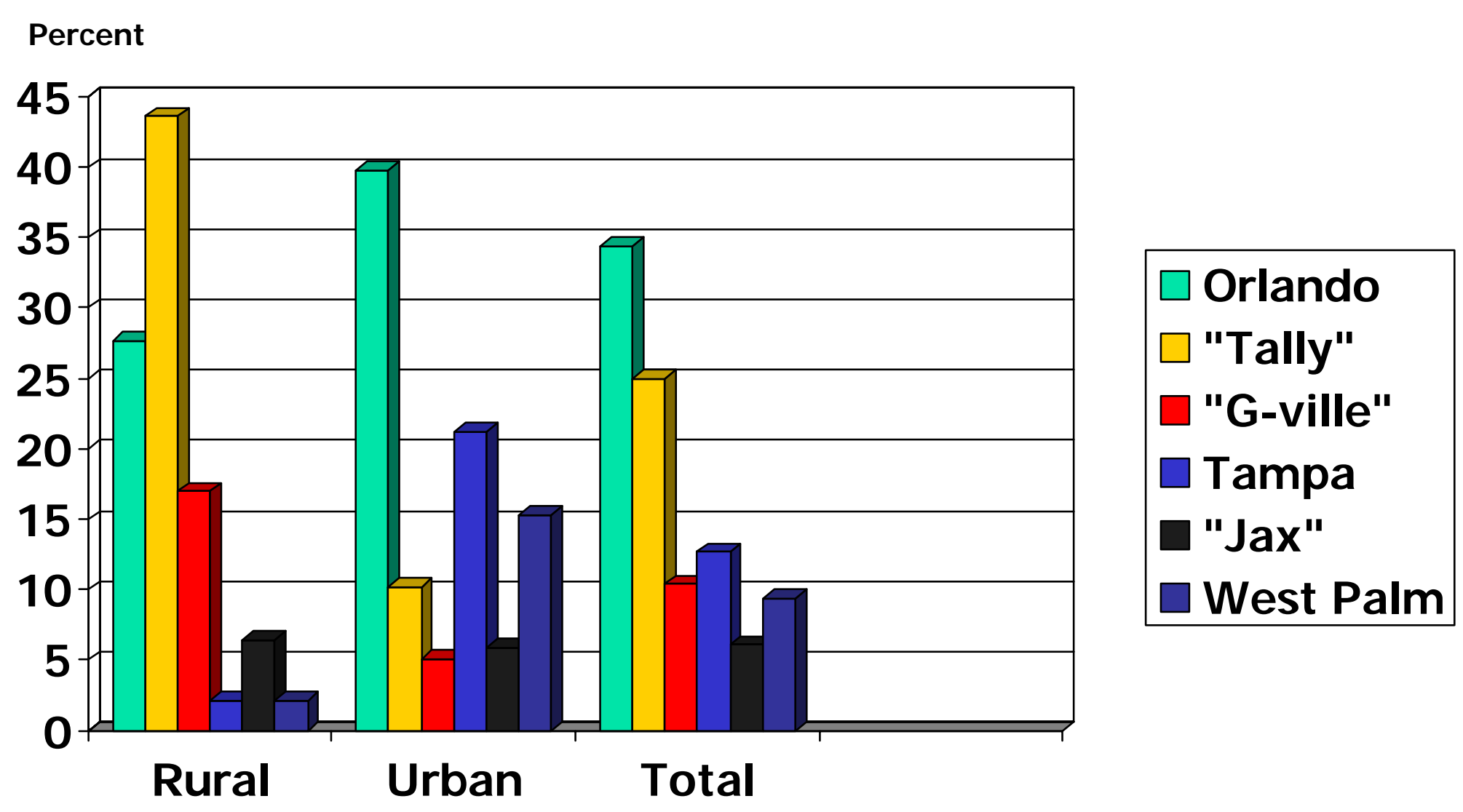




\section{Do You Prefer Single Or Multiple Subject Workshops}

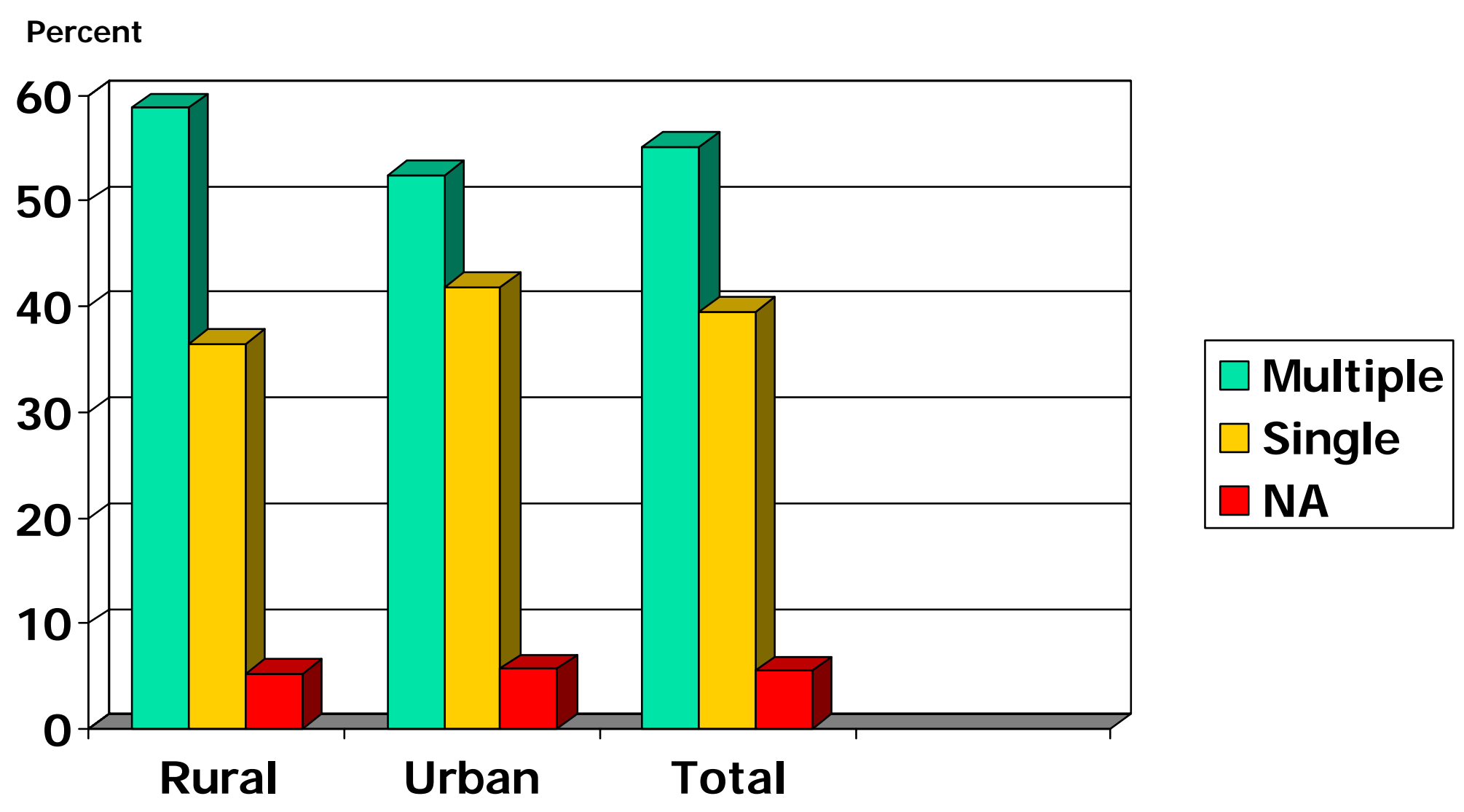




\section{What's The Most You Would Pay For Educational Workshop Fees}

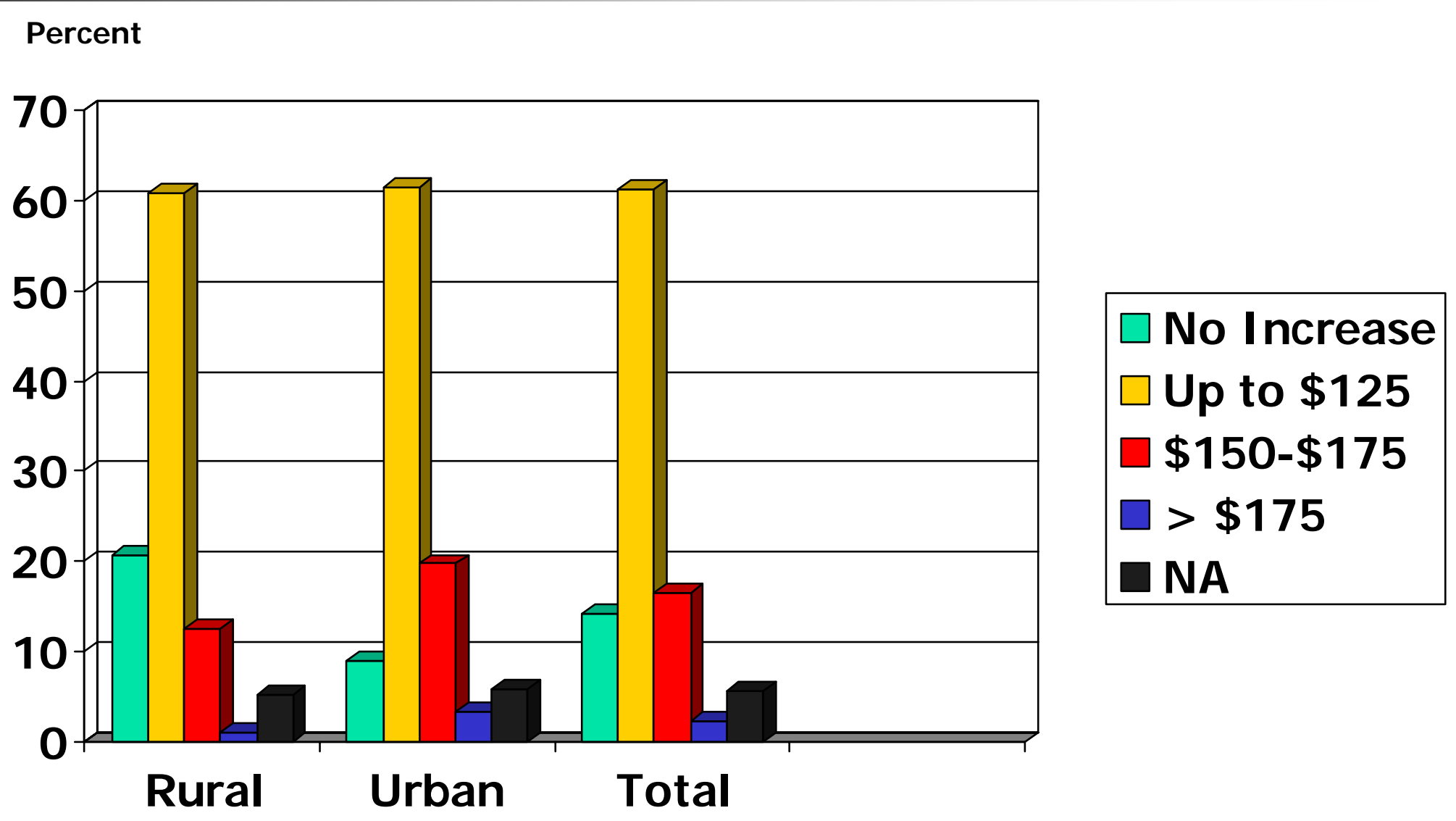




\section{Most I mportant Factors I nfluencing Workshop Attendance}

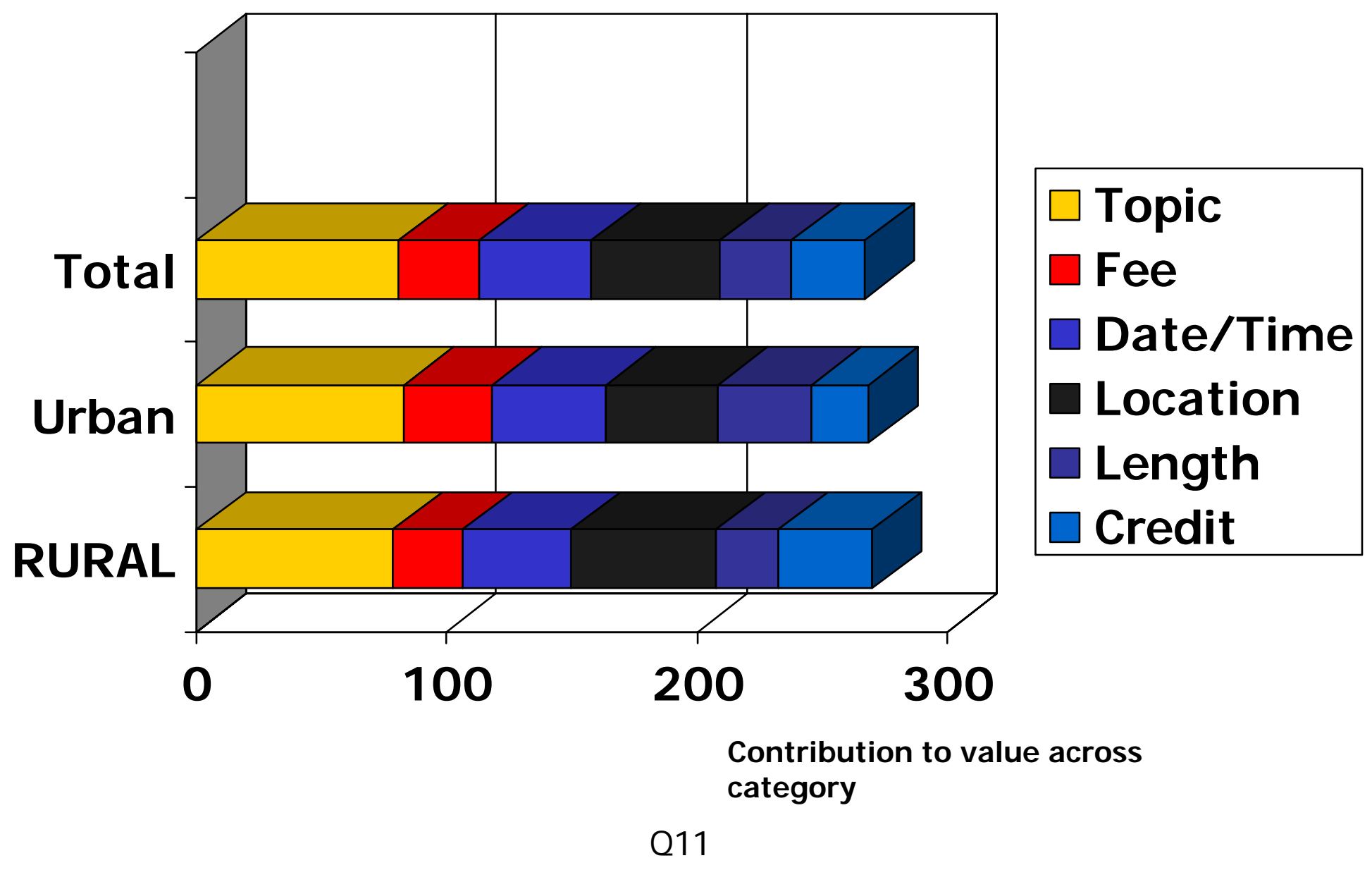




\section{The CCC Program Should Be Continued}

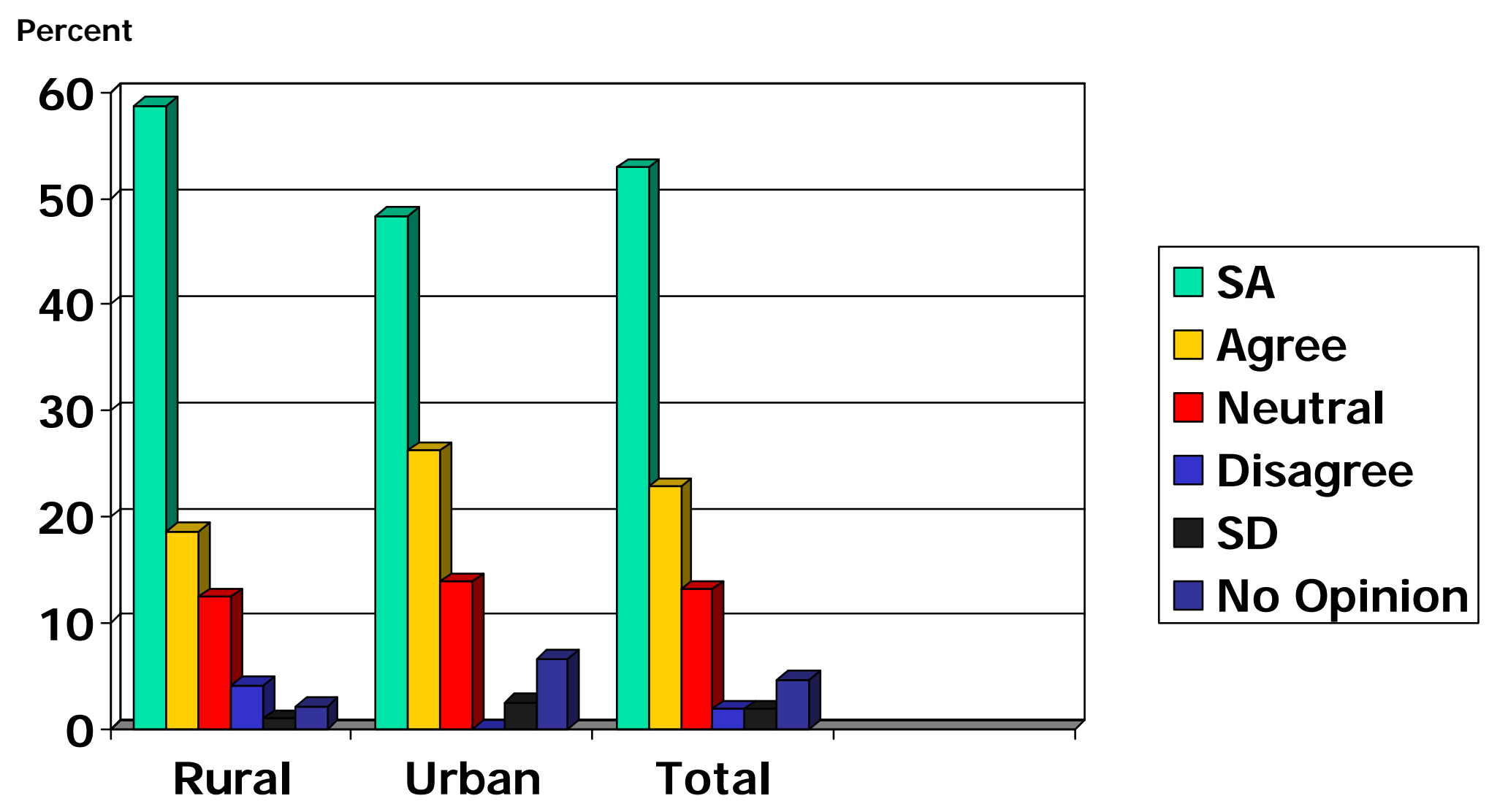

Q12 


\section{Five Most I mportant Training Needs (weighted)}

Weighted Score

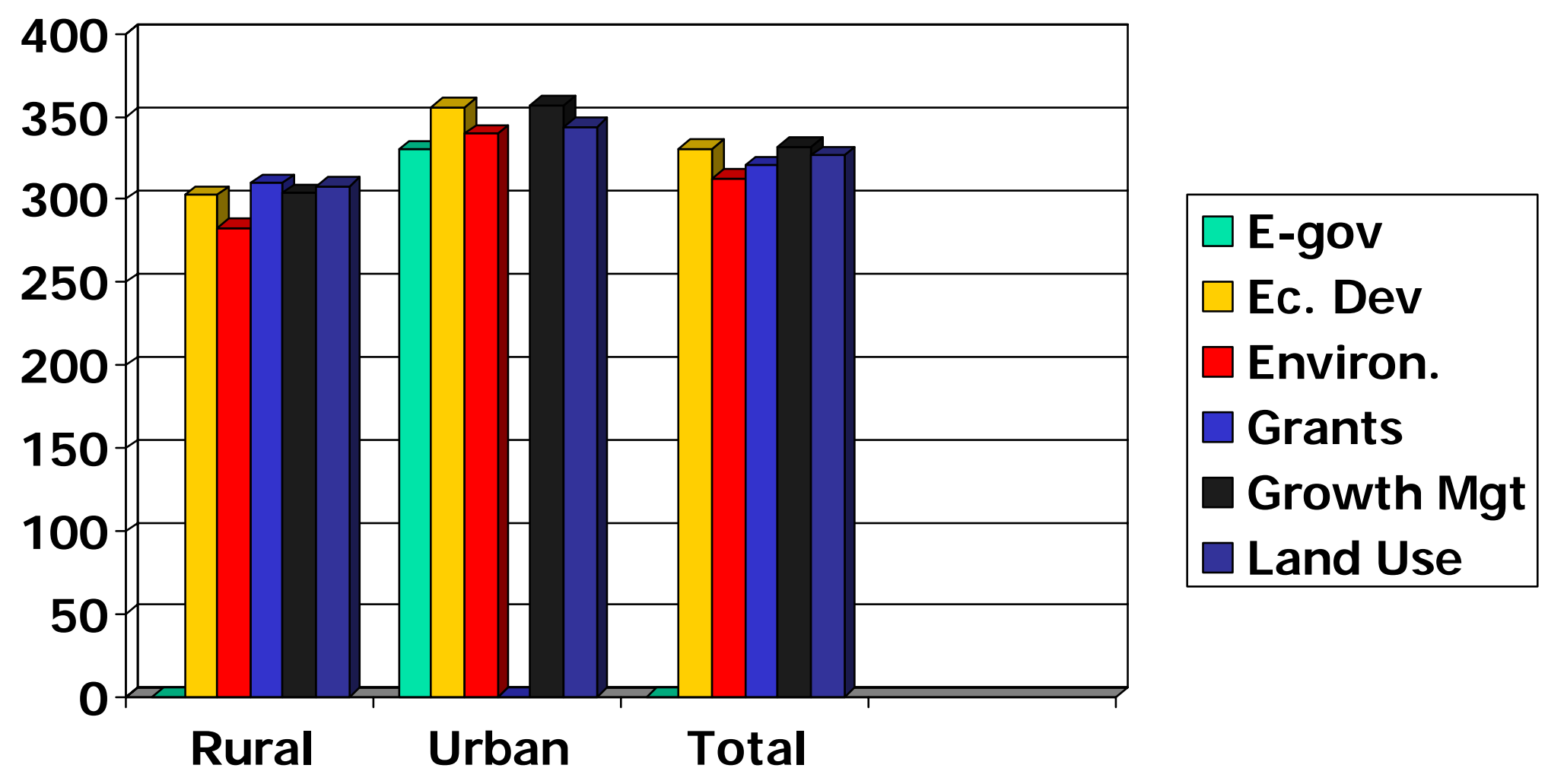




\section{Three Most I mportant Topics (Total Votes)}

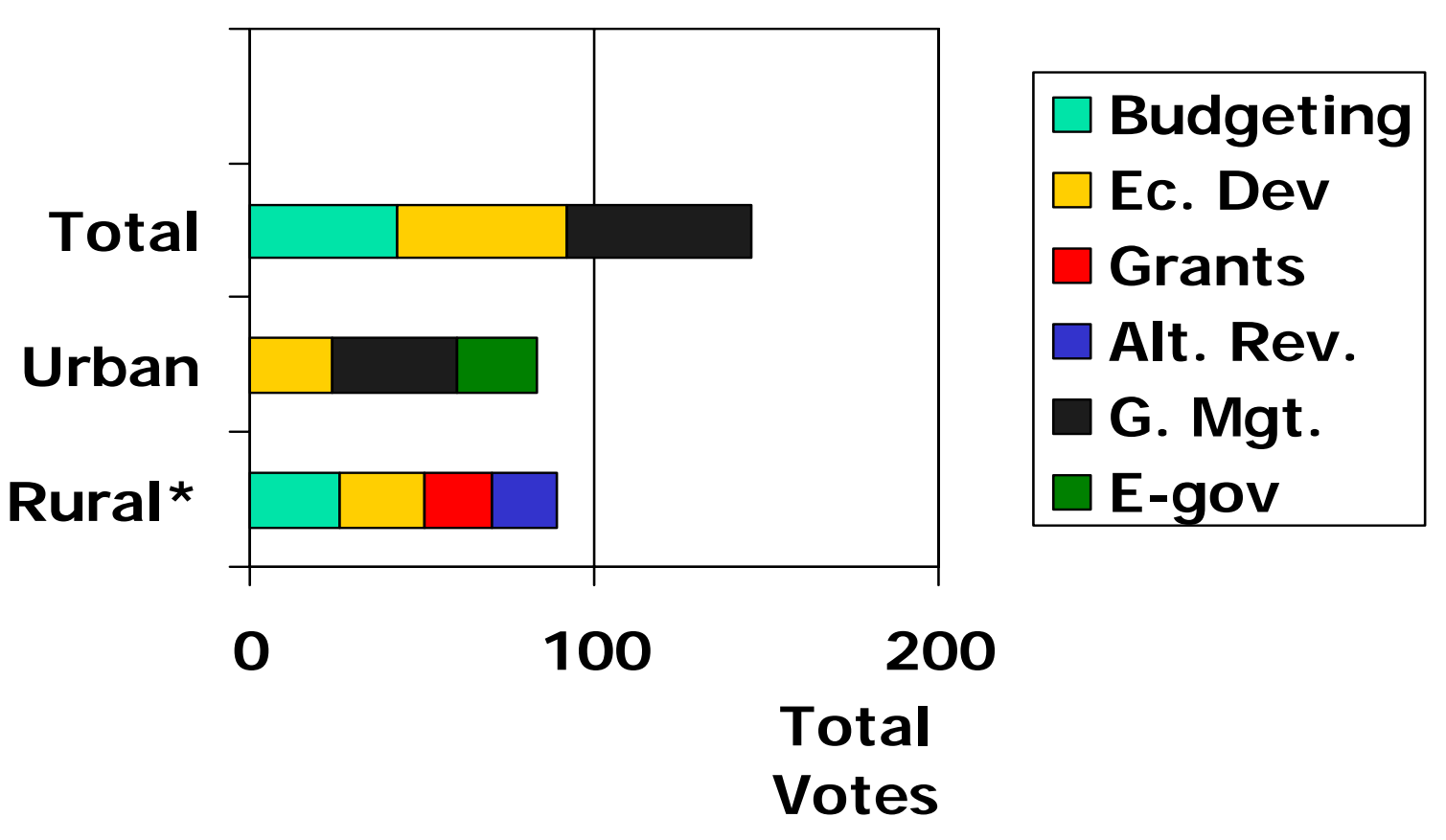

* Grants and Alternative Revenues tied for third 


\section{Are You A CCC Graduate}

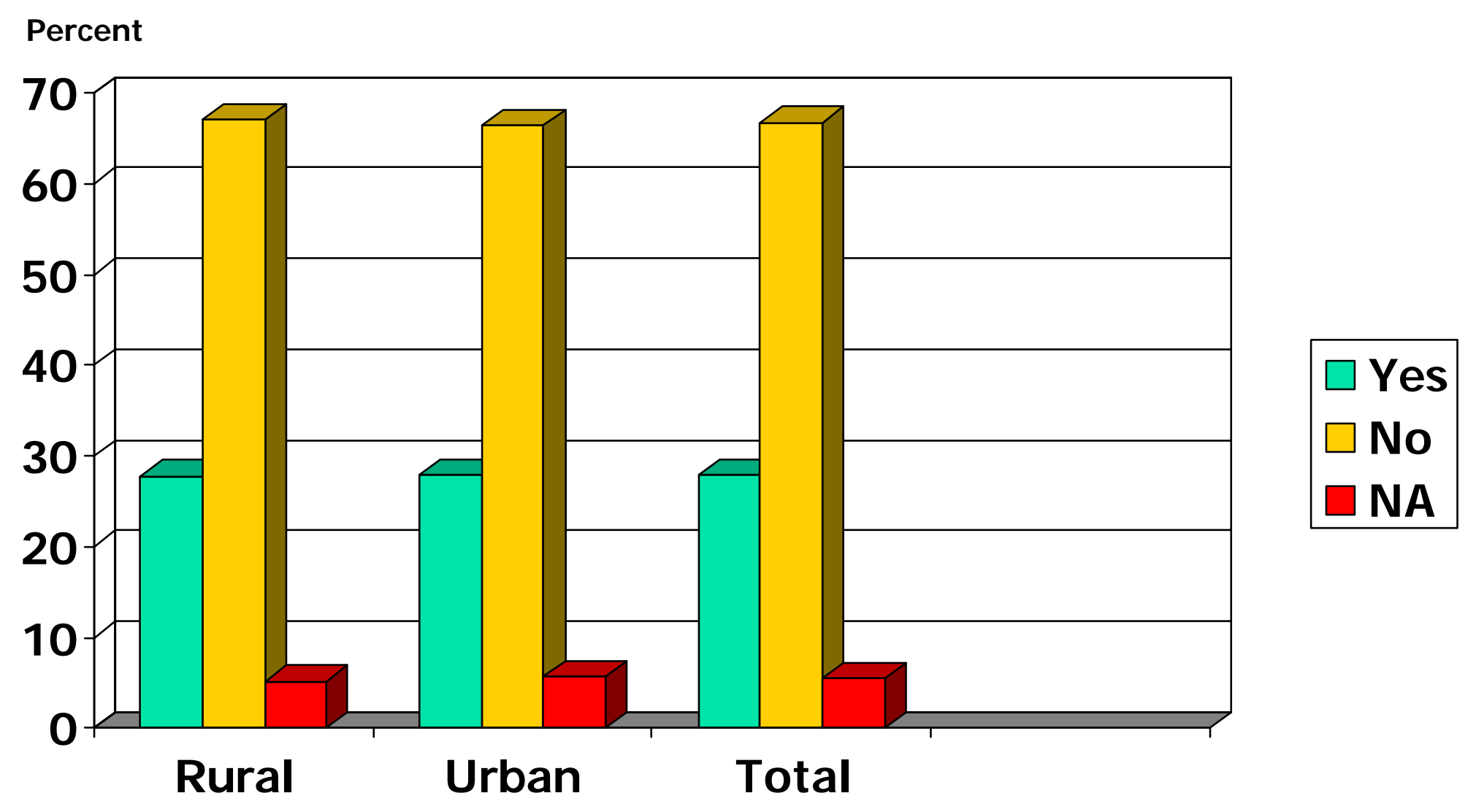




\section{Would You Attend An Alumni Event For CCC Graduates}

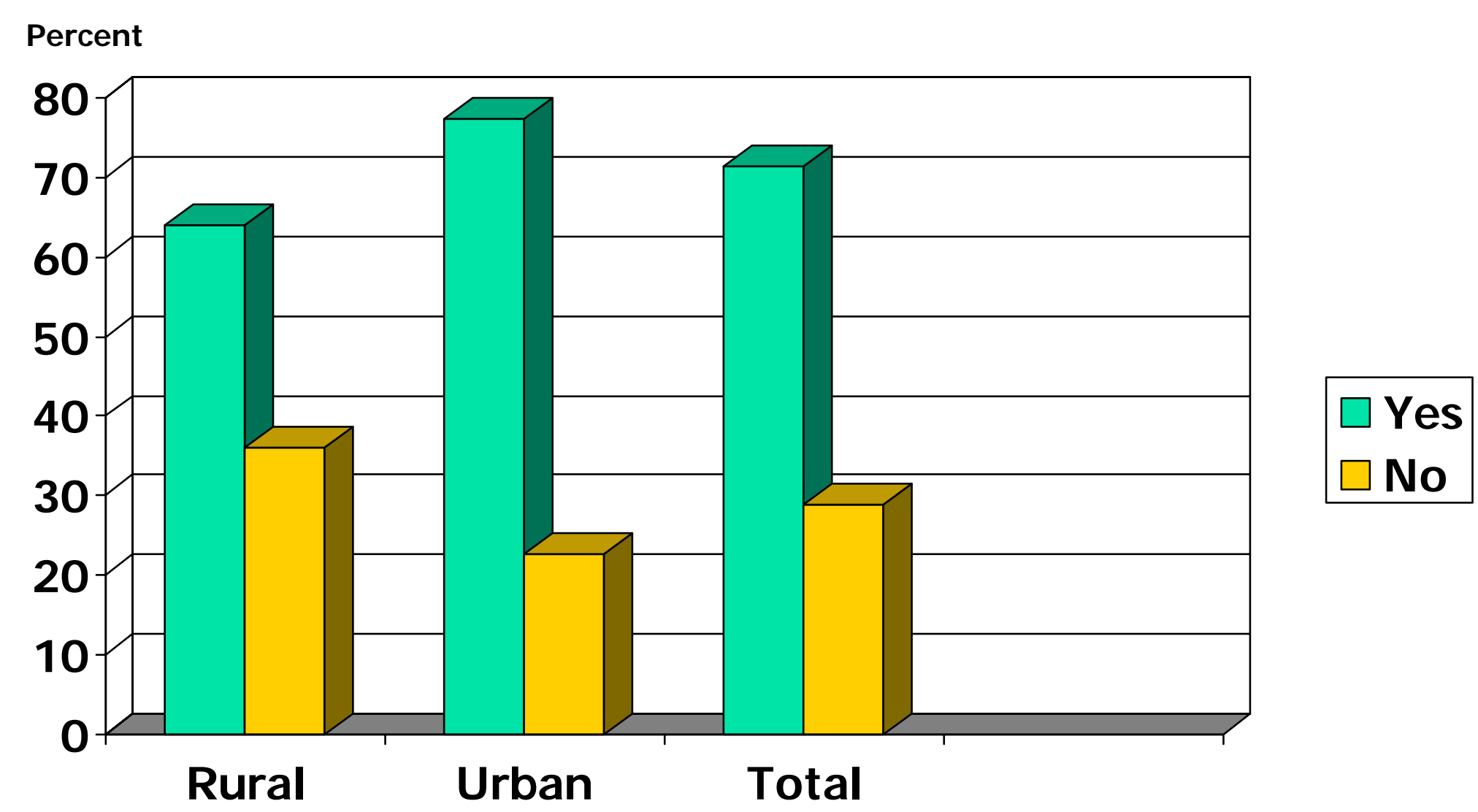




\section{Would You Participate In An Advanced Curriculum Program For CCC Graduates Only}

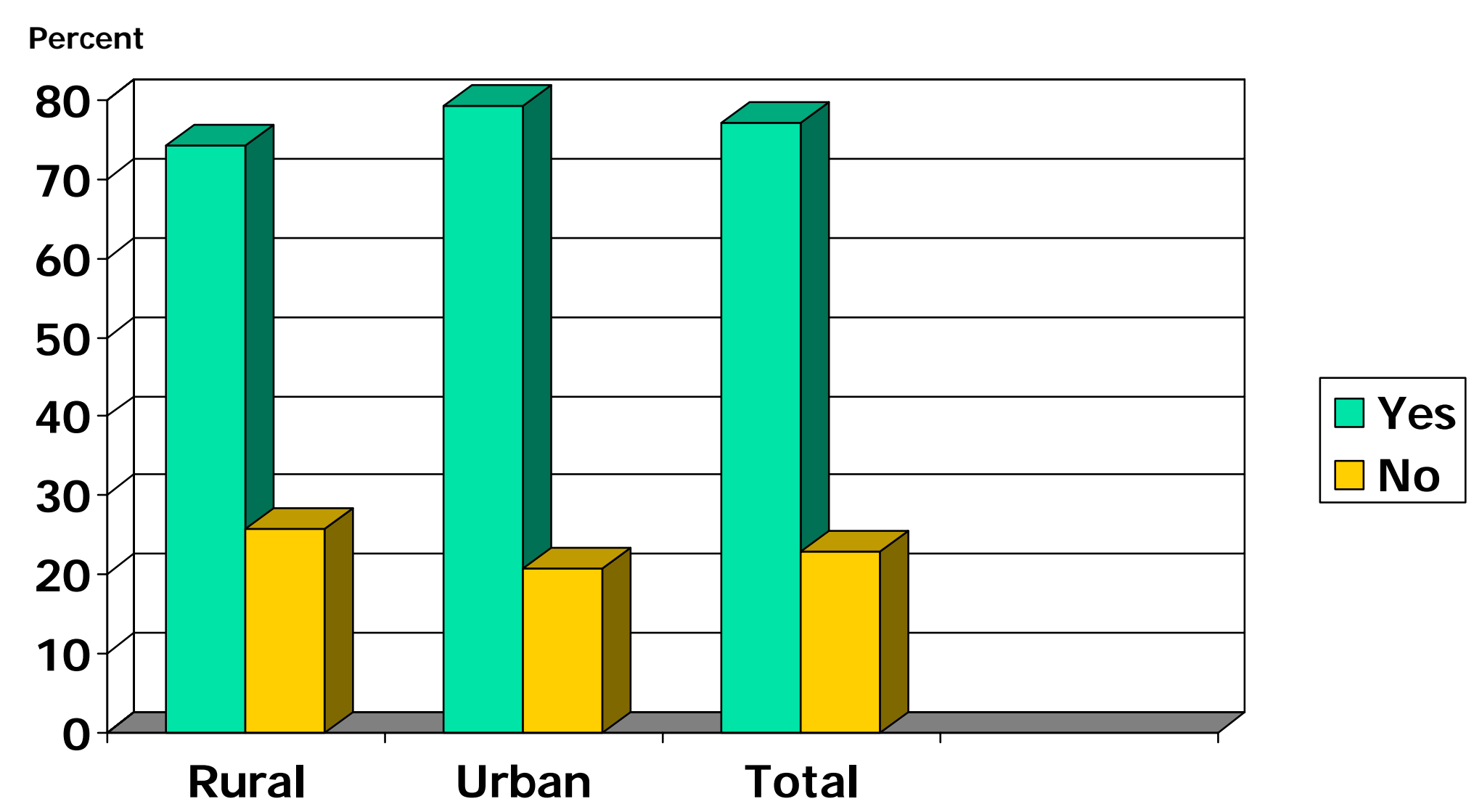




\section{How Many Years Have You Been In Your Current Position}

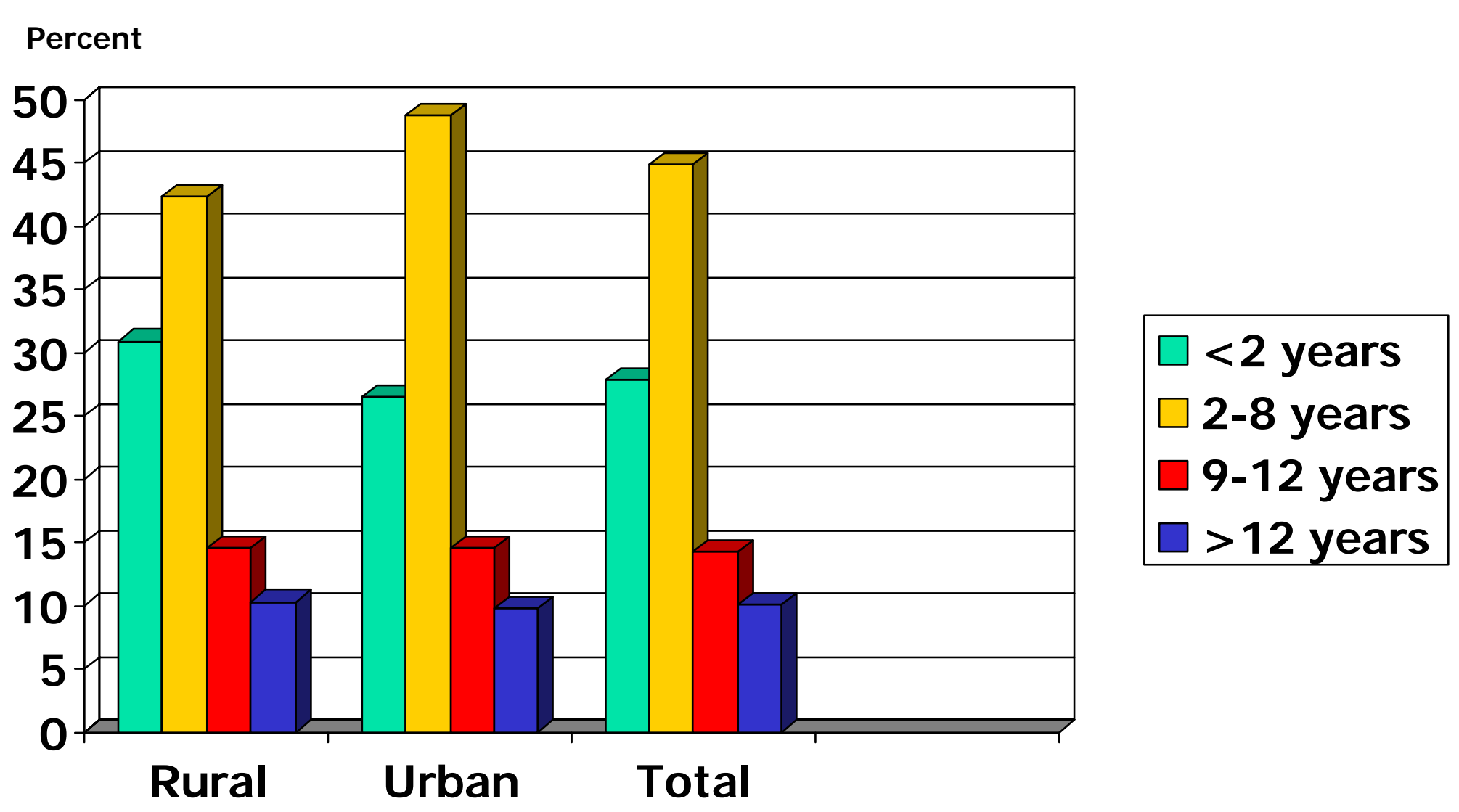

